\title{
A Model for Optimal Treatment of Cassava Wastewater Using Anaerobic Baffled Reactor
}

\author{
A. O. Ibeje $\mathrm{e}^{*}$, E. Onukwugha ${ }^{2}$ \\ ${ }^{1}$ Department of Civil Engineering, Imo State University, Owerri, Nigeria. \\ ${ }^{2}$ Department of Civil Engineering, Federal Polytechnic, Nekede, Owerri, Nigeria.
}

ABSTRACT: The major components of the effluents from cassava processing industries are cyanide and starch. However it is suspected that cyanide inhibits the treatment of cassava wastewater. The experimental data were successfully fitted to a polynomial model which was used to optimize the treatment processes at a laboratory scale. The Monod and Michealis-menten models for cassava wastewater treatment was successfully calibrated and validated in an ABR system. For Michealis-Menten model, the maximum substrate utilization rate is estimated in the range: 2866.88 to $1432.84 \mathrm{mgl}-1$ and for Monod's model, it is estimated in the range: 493 to $1242 \mathrm{mgl}-1$, which is more realistic, hence validating the empirical model as more accurate than the former, which is theoretical. The result revealed that the inhibitor constant decreased from 9.9989 to $1.6101 \mathrm{mgl}-1$ as the number of baffles increased from 3 to 10 . To reach a maximum COD removal efficiency of $99 \%$, it was found that the aspect ratio of 10,20 baffles, cyanide inhibition constant of $30 \mathrm{mg} / \mathrm{l}$ and influent flow rate of $0.8 \mathrm{l} / \mathrm{min}$, are the required optimum operating conditions of the anaerobic baffled reactors.

KEYWORDS: Anaerobic baffled reactor, Cassava Wastewater, COD removal, Optimal treatment, Kinetic coefficients

\section{Notation}

$\mathrm{S}_{\mathrm{o}}=$ Influent COD at the start of each of the experimental case, $\mathrm{mg} / \mathrm{l}, \mathrm{X}_{\mathrm{o}}=$ Influent suspended solids at the start of each case, $\mathrm{mg} / \mathrm{l}, \mathrm{I}=$ Inhibitor (cyanide) concentration at the start of each case, $\mathrm{mg} / \mathrm{l}, \mathrm{S}=$ Effluent COD after the first step of each case, $\mathrm{mg} / \mathrm{l}, \mathrm{X}=$ Effluent suspended solids, $\mathrm{mg} / \mathrm{l}, \mathrm{k}_{\mathrm{s}}=$ Half saturation constant, $\mathrm{mgl}^{-1}, \mu=$ Specific growth rate of organism, day ${ }^{-1}$, $\mu_{\max }=$ Maximum specific growth rate of organism, day ${ }^{-1}, \mathrm{k}_{\mathrm{d}}=$ Endogenous decay coefficient, minute ${ }^{-1}, \mathrm{Y}=$ Cell yield coefficient, ratio of the mass of cells formed to the mass of substrate consumed, $\mathrm{mg} / \mathrm{mg}, \mathrm{k}=$ Maximum rate of substrate utilization per unit mass of micro-organisms, minute ${ }^{-1}, \mathrm{k}_{\mathrm{s}}=$ Half velocity constant, substrate concentration at one-half of the maximum growth rate, $\mathrm{mg} / \mathrm{l}, \mathrm{K}_{\mathrm{r}}=$ Overall COD removal rate constant, minute ${ }^{-1}, \mathrm{~K}_{\mathrm{m}}=$ Michaelis-Menten constant, $\mathrm{mg} / \mathrm{l}$, $\mathrm{K}_{\mathrm{i}}=$ Inhibition constant, $\mathrm{mg} / \mathrm{l}, \mathrm{V}_{\mathrm{r}}=$ Reactor volume, $1, \mathrm{~L} / \mathrm{W}=$ Length-width ratio, $\mathrm{N}_{\mathrm{b}}=$ Number of baffles, $\mathrm{Q}=$ Flow rate, $1 / \mathrm{min}, \mathrm{HRT}=$ Hydraulic retention time, $\min =\mathrm{V}_{\mathrm{w}} / \mathrm{Q}$.

\section{INTRODUCTION}

In most developing countries of sub-Saharan Africa as well as Asian countries, cassava (Manihot esculenta) has become a popular source of Carbohydrates (Eze and Azubuike, 2010). Cassava wastewater is an industrial residue obtained during the processing of cassava into various fermented products such as Garri, Fufu. Ubalua (2007) suggested the use of microorganisms to convert cassava wastes to value-added components such as Methane (biogas), Ethanol, surfactants

*Corresponding author: engineeribeje@ gmail.com and fertilizers etc. Adewoye et al. (2005) showed that the physio-chemical characteristics, including dissolved Oxygen $(\mathrm{DO}=0.74 \mathrm{mg} / \mathrm{l})$, biochemical oxygen demand $(\mathrm{BOD}=185$ $\mathrm{mg} / \mathrm{l})$, total suspended solids (TSS $=87 \mathrm{mg} / \mathrm{l})$, of the cassava wastewater deviated from the FEPA (1991) standard (DO = 5.0 $\mathrm{mg} / \mathrm{l}, \mathrm{BOD}=50 \mathrm{mg} / \mathrm{l}, \mathrm{TSS}=30 \mathrm{mg} / \mathrm{l}$ ) for the maximum limit allowable for effluent discharge into water bodies.

Even Okunade and Adakalu (2013) asserted that cyanide has been always present in cassava wastewater as Cyanogenic Glycosides which hydrolyzes to harmful form as Hydrocyanic acid (Olayinka, 2013). In addition, the degraded cassava peels were said to contain hydrocyanic acid and generated objectionable odor (Okunade and Adakalu, 2013). According to WHO (2006), NIS (2007), high concentration of cyanide $(>0.01 \mathrm{mg} / \mathrm{l})$ in water is very dangerous to human health because cyanide affects the Thyroid and the central nervous system; leading to paralysis. Oghenejoboh (2015) proved that cassava wastewater contained pollutants that are deleterious to natural fish population. High biochemical oxygen demand present in cassava wastewater, depletes the dissolved oxygen (DO) needed for the survival of aquatic life in the receiving water bodies (Adegoke et al., 2020).

However, Igwe and Azorji (2018) showed that the cyanide content of the cassava effluent could serve as an efficient source of nutrient to the soil and thus to crops, making it an alternative to mineral fertilizer. According to Ogbohodo et al. (2001), cassava effluent increased the number of organisms in the soil ecosystem as well as the soil pH, organic carbon and total Nitrogen, even favorable effects such as 
improved absorption of Nitrogen by maize were also reported at a soil $\mathrm{pH}(>7.5)$ and a soil saturation of $90 \%$.

However, due to the toxic materials present in cassava wastewater, simple and efficient technologies for cassava wastewater treatment have evolved. Ribas et al. (2010) observed that anerobically treated cassava wastewater was more stable with the conservation of the mineral of the raw wastewater. Ugwu and Agunwamba (2012) drastically reduced the coliform count and BOD in Cassava wastewater such that higher concentration of $\mathrm{NaOH}$ led to increased $\mathrm{pH}$, which favored the growth of alkali bacteria, reduced cyanide level to $2 \mathrm{mg} / \mathrm{l}$ and BOD to $20 \%$ after 20 days of alkali hydrolysis. Ensiling of cassava residues, which involves grinding, salting and compaction of Cassava residues, has also increased the anaerobic bacteria through fermentation of cassava residues, thus lowering the cyanide concentration to non-toxic level and decreasing the levels of organic acids (acetic and butyric acid) while increasing lactic acid concentration (Nguyen et al., 1997).

To degrade cassava wastewater to environmentally acceptable forms, there is a need for information concerning the degradation kinetics; which is useful in the design of efficient treatment plants. To this end, BOD kinetic constants were obtained as $0.432 \mathrm{~d}^{-1}$ and $0.152 \mathrm{~d}^{-1}$ for Garri and fermented cassava wastewater respectively treated in the activated sludge process (Agunwamba, 2004). Ibeje and Okoro (2013) used the COD kinetics to show that the Monod model best described the rate of COD removal in cassava wastewater treated using the Anaerobic baffled reactors (ABR), then the kincannon-Stover model. Also, Onukwagha and Ibeje (2013) used the COD and cyanide kinetics to show that the extent of cyanide inhibition in cassava wastewater treatment in ABR was minimal. Despite these accomplishments, Onukwugha et al. (2016) further tried to study the scale effect of the ABR, by considering three reactors of aspect ratios: 53:16:30; 4:1:1; 10:3:6 in the kinetic analysis of cassava wastewater to obtain the specific growth rates as 10.87 day $^{-1} ; 12.82$ day $^{-1}$ and 13.70 day $^{-1}$ respectively, using the Monod's model. Yet the suitable condition for the desired optimal removal of organics was not ascertained.

Cassava wastewater, generated by subsistence farmers in Ohaji-Egbema areas of Imo State, Nigeria, is discharged freely into open channels, gutters, streams, ponds etc. causing the eutrophication of streams in the area. In view of this fact, there is a need to adopt wastewater treatment option that optimizes the degradation of cassava wastewater. This study is therefore focused on finding the optimal conditions for the removal of organics from cassava wastewater using ten $\operatorname{ABR}(\mathrm{s})$. The approach adopted in this study begins with the reactors startup and data collection mode after introducing the wastewater to the reactor. The treatment kinetics are thereafter obtained, the relationship between the reactors operating variables: aspect ratio, number of baffles, inhibition constant, flow rate and the COD removal rate are also obtained. The model is thus validated and used to reveal the optimal operating conditions of the reactors.

\section{MATERIALS AND METHODS}

\section{A. Experimental Procedure}

A typical ABR consists of a series of vertical baffles that direct the wastewater under and over the baffles as it passes from the inlet to the outlet, which enable the ABR to retain active biological mass (bacteria) without the use of any fixed media (Watthier et al., 2019). Anaerobic digestion that takes place in an ABR involves the use of different groups of organisms: the hydrolytic fermentative (acidogenic) bacteria that hydrolyze the complex polymer substrate to alcohols, sugars, hydrogen, and carbondioxide; acetogenic organisms that convert fermentation products into acetate and carbon dioxide and the methanogens that convert simple compounds such as acetic acid, methanol into methane.

Ten ABRs of different sizes as given in Table 1 were made from $6 \mathrm{~mm}$ thick stainless steel; an example is shown in Figure 1 . The reactors had equal number of compartments for proper mixing and each compartment had sampling port. Water bath was used to regulate the reactor temperature at $35+0.5^{\circ} \mathrm{C}$ and a variable speed peristaltic pump was used to pump the influent feed. The wastewater was collected from the cassava processing units at Ohaji-Egbema Local Government Area of Imo State and was filtered to $90 \%$ total suspended solid, before it was fed into the reactor. At any given loading rate, the bioreactor was continuously operated until steady-state condition was achieved. The ABR were operated at different selected values of the hydraulic retention time (HRT), influent flow rate $(\mathrm{Q})$ and organic loading rate. These selected values were described as cases in Table 2 and symbols have been defined earlier in the notation section. The wastewater samples were collected twice a week for physio-chemical analysis.

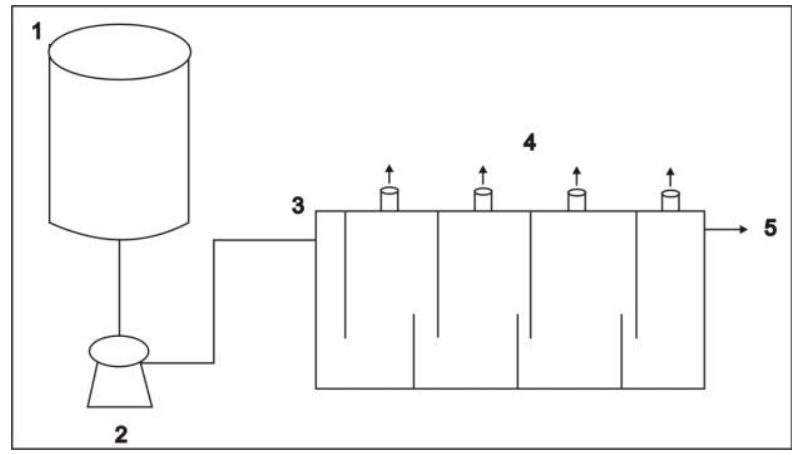

1. Feed tank; 2. Peristaltic pump; 3. Influent; 4. Sampling ports; 5. Effluent. Figure 1: Scheme of the ABR.

Table 1: Geometric features of the reactors.

\begin{tabular}{lrrrrrrrrrr}
\hline Reactors & $\mathbf{1}$ & $\mathbf{2}$ & $\mathbf{3}$ & $\mathbf{4}$ & $\mathbf{5}$ & $\mathbf{6}$ & $\mathbf{7}$ & $\mathbf{8}$ & $\mathbf{9}$ & $\mathbf{1 0}$ \\
\hline Aspect Ratio (L/W) & 0.4 & 0.5 & 0.6 & 0.7 & 0.8 & 0.9 & 1 & 1.1 & 1.2 & 1.3 \\
Number of Baffles $\left(\mathrm{N}_{\mathrm{b}}\right.$ ) & 3 & 4 & 5 & 6 & 7 & 8 & 9 & 10 & 11 & 12 \\
Volume (litre) & 10 & 10 & 10 & 10 & 10 & 10 & 10 & 10 & 10 & 10 \\
\hline
\end{tabular}


Table 2: Definition of the cases of cassava wastewater treatment.

\begin{tabular}{cccccccc}
\hline Reactor & $\mathbf{Q}$ & $\mathbf{H R T}$ & $\mathbf{S}_{\mathbf{o}}$ & $\mathbf{X}_{\mathbf{o}}$ & $\mathbf{I}$ & $\mathbf{S}$ & $\mathbf{X}$ \\
\hline 1 & 0.4 & 25 & 2189 & 10680 & 120 & 408 & 412.896 \\
2 & 0.3148 & 31.7662 & 2060 & 10560 & 109 & 384 & 388.608 \\
3 & 0.2796 & 35.76538 & 2000 & 10503 & 98 & 368 & 372.416 \\
4 & 0.2444 & 40.91653 & 1970 & 10467 & 88 & 352 & 356.224 \\
5 & 0.2092 & 47.80115 & 1930 & 10410 & 76 & 332 & 335.984 \\
6 & 0.1739 & 57.50431 & 1900 & 10032 & 64 & 308 & 311.696 \\
7 & 0.1287 & 77.70008 & 1850 & 9600 & 52 & 300 & 303.6 \\
8 & 0.1035 & 96.61836 & 1810 & 9207 & 43 & 276 & 279.312 \\
9 & 0.0683 & 146.4129 & 1750 & 8796 & 31 & 240 & 242.88 \\
10 & 0.0331 & 302.1148 & 1700 & 8400 & 20 & 204 & 206.448 \\
\hline
\end{tabular}

By adopting the approach by Onukwugha (2015), the COD removal efficiency (RE) was formulated in Equation 1 as a polynomial function of ten-level experimental runs of four independent factors: the reactors' aspect ratio $(\mathrm{L} / \mathrm{W})$, number of baffles $\left(\mathrm{N}_{\mathrm{b}}\right)$, the inhibition constant $\left(\mathrm{k}_{\mathrm{i}}\right)$ and flow rate $(\mathrm{Q})$.

$R E=m(L / W)^{a_{1}}\left(N_{b}\right)^{a_{2}}\left(K_{i}\right)^{a_{3}}(Q)^{a_{4}}$

According to Ibeje et al. (2019), the COD removal efficiency of the reactor was estimated for each of the 10 cases as:

$$
R E=\left(S_{o}-S\right) / S_{o}
$$

where the terms retain their meanings as given in the notation section.

According to Potivichayanon et al. (2020), the mathematical model for cassava wastewater treatment without considering inhibition is given as the Monod model as:

$r_{A}=\frac{d s}{d t}=\frac{Q}{V}\left(S_{o}-S\right)=\mu . X \quad=\frac{\mu_{\max } S}{K_{S}+S} X$

where the terms retain their meanings as given in the notation section.

If $\mathrm{K}_{\mathrm{s}}$ is replaced with $\mathrm{K}_{\mathrm{m}}$, Eq. (3) gives the Michaelis-Menten model and simplifying the expression gives:

$$
\frac{X V}{Q\left(S_{o}-S\right)}=\frac{K_{m}}{\mu_{\max }} \frac{1}{S}+\frac{1}{\mu_{\max }}
$$

The mathematical modelling of cassava wastewater treatment with cyanide inhibition is also given by Potivichayanon et al. (2020) as in Eq. (5).

$\mu_{g}=\frac{\mu_{\max }}{1+\frac{K_{S}}{S_{o}}+\frac{I}{K_{i}}}$

Replacing $\mu_{\mathrm{g}}$ with $\mu$ in Eq (5) and substituting $\mu$ with its equivalent definition as given in Eq. (3), then the inverse and simplified form of $\mathrm{Eq}(5)$ is:
Substituting and replacing $\mu$ and $\mu_{\mathrm{g}}$, then taking inverse and simplifying the expression gives:

$\frac{x V}{Q\left(S_{o}-S\right)}=\frac{1}{\mu_{\max }}+\frac{K_{S}}{\mu_{\max }} \cdot \frac{1}{S}+\frac{1}{\mu_{\max } K_{i}}$

From Tables 2 and 4, the intercepts and slopes of the graphs of $\mathrm{Q}\left(\mathrm{S}_{\mathrm{o}}-\mathrm{S}\right) / \mathrm{V}_{\mathrm{w}} \mathrm{X}_{\mathrm{o}}$ against $1 / \mathrm{HRT}$ were used to obtain $\mathrm{k}_{\mathrm{d}}$ and $\mathrm{Y}$ for each of the cases, using: $\mathrm{K}_{\mathrm{d}}=$ intercept/slope and $\mathrm{Y}$ $=1 /$ slope (Potivichayanon et al., 2020). To obtain $\mathrm{k}$ and $\mathrm{k}_{\mathrm{s}}$ using: $\mathrm{k}=1 /$ intercept and $\mathrm{k}_{\mathrm{s}}=$ slope/intercept, the intercepts

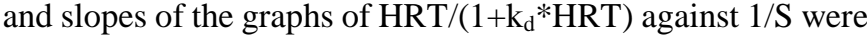
used (Potivichayanon et al., 2020). The slopes of the graphs of $\mathrm{Q}\left(\mathrm{S}_{\mathrm{o}}-\mathrm{S}\right) / \mathrm{V}_{\mathrm{w}}$ against $\mathrm{S}$ were used to obtain $\mathrm{K}_{\mathrm{r}}$ for each of the cases using: $\mathrm{K}_{\mathrm{r}}=$ slope. Using: $\mathrm{K}_{\mathrm{m}}=$ slope/intercept, the intercepts and slopes of the graphs of $1 / \mathrm{Q}$ against $1 / \mathrm{S}$ were used to obtain $\mathrm{K}_{\mathrm{m}}$. It should be noted that the variables were as defined in the notation section.

\section{RESULTS AND DISCUSSION}

\section{A. Cassava Wastewater Characterization}

Table 3 shows the results of the tests at the Imo State Polytechnic Umuagwo in 2019 on the raw wastewater prior to treatment. The COD and BOD concentrations in the wastewater are evidently very high, thus the free discharge of untreated wastewater would definitely lead to environmental pollution.

\section{B. Results of Estimated Kinetic Coefficients}

Generally, the values of kinetic constants presented in Tables 4 are within the normal range of ABR process found in previous studies by Ibeje and Okoro (2013). For MichealisMenten model, the maximum substrate utilization rate is estimated in the range: 2866.88 to $1432.84 \mathrm{mgl}^{-1}$ at a coefficient of determination, $\mathrm{R}^{2 \%}$ of $53 \%$ and for Monod's model, it is estimated in the range: 493 to $1242 \mathrm{mgl}^{-1}$ at $\mathrm{R}^{2} \%$ of $84 \%$.

Table 4: Estimated kinetic coefficients of abr-treated cassava wastewater.

\begin{tabular}{ccccccc}
\hline Reactor & $\mathbf{K}_{\mathbf{d}}$ & $\mathbf{Y}$ & $\mathbf{k}$ & $\mathbf{k}_{\mathbf{s}}$ & $\mathbf{K}_{\mathbf{m}}$ & $\mathbf{K}_{\mathbf{r}}$ \\
\hline 1 & 0.138 & 1.026 & 2.03 & 1243 & 2865.88 & 13.577 \\
2 & 0.137 & 1.36 & 2.02 & 1171 & 2697.14 & 10.683 \\
3 & 0.136 & 1.55 & 1.99 & 1111 & 2584.41 & 9.646 \\
4 & 0.137 & 1.779 & 1.95 & 1040 & 2472.5 & 8.747 \\
5 & 0.137 & 2.076 & 1.9 & 953 & 2331.72 & 7.849 \\
6 & 0.138 & 2.414 & 1.85 & 853 & 2163.43 & 7.018 \\
7 & 0.137 & 3.175 & 1.83 & 831 & 2107.1 & 5.192 \\
8 & 0.138 & 3.828 & 1.79 & 740 & 1938.53 & 4.499 \\
9 & 0.139 & 5.624 & 1.73 & 615 & 1685.74 & 3.369 \\
10 & 0.142 & 11.19 & 1.66 & 493 & 1432.84 & 1.908 \\
\hline
\end{tabular}

Table 3: Average characteristics of the cassava wastewater used in the study.

\begin{tabular}{cccccccc}
\hline $\begin{array}{c}\text { Wastewater } \\
\left(\mathbf{m}_{\mathbf{3}} / \mathbf{l}\right.\end{array}$ & $\mathbf{p H}$ & $\begin{array}{c}\text { Total } \\
\text { solids } \\
\mathbf{s t a r c h})\end{array}$ & $\begin{array}{c}\text { Suspended } \\
\text { solids } \\
(\mathbf{m g} / \mathbf{1})\end{array}$ & $\begin{array}{c}\text { Total } \\
\text { dissolved }\end{array}$ & $\begin{array}{c}\text { BOD } \\
(\mathbf{m g O} / \mathbf{1})\end{array}$ & $\begin{array}{c}\text { COD } \\
(\mathbf{m g O} / \mathbf{1})\end{array}$ & $\begin{array}{c}\text { Total nitrogen } \\
(\mathbf{m g} \mathbf{N} / \mathbf{1})\end{array}$ \\
\hline $\mathbf{2 5}$ & 4.5 & 7604 & 2642 & 6483 & 3608 & 8842 & 172 \\
\hline
\end{tabular}


Based on the previous studies in describing the treatment kinetics of the cassava wastewater by Ibeje and Okoro (2013), the range of the maximum substrate utilization rate obtained from the Monod's model appears to be more realistic than the range of values obtained from the Michealis-Menten model, hence validating the accuracy of the empirical model when compared with the former, which is theoretical. Figures 2 and 3 show the variation of the kinetic coefficient with the inhibition coefficient, $\mathrm{K}_{\mathrm{i}}$. The $\mathrm{K}_{\mathrm{d}}$ and $\mathrm{Y}$ intersect in Figure 2 at a value of $2000 \mathrm{mins}^{-1}$. The maximum growth rate was estimated to be between 0.138 to $0.142 \mathrm{~min}^{-1}$ for cassava wastewater treatment (Agunwamba et al., 2001). This value is a little lower than the values obtained by Onukwugha et al. (2016). Also, Mantzaris (2002), studied the effect of cyanide concentration on COD removal efficiency and obtained similar graphs as the one shown in Figure 4.

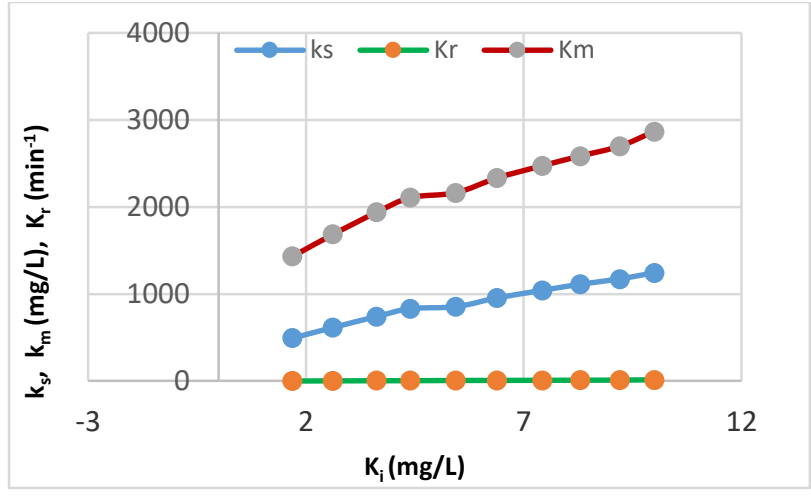

Figure 2: Influence of cyanide inhibition (Ki) on the rates of substrate consumption (Ks, Km).

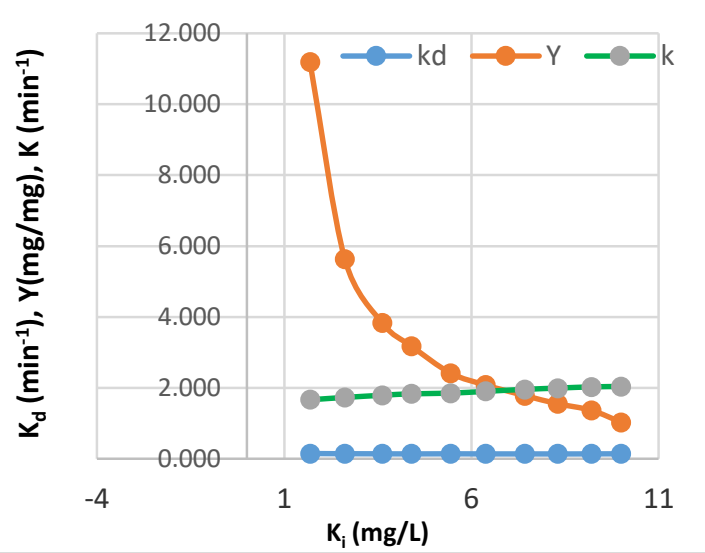

Figure 3: Cyanide inhibition $\left(K_{i}\right)$ of cannibalism by microbes $\left(k_{d}\right)$ and their rate of substrate uptake $(K, Y)$.

According to Figure 4, at first glance, the point of defection clearly indicates the occurrence of inhibition. Here the COD removal efficiency dropped from $88 \%$ to $84 \%$ between a cyanide concentration of 10 to $50 \mathrm{mg} / \mathrm{l}$. It remained constant between 50 and $70 \mathrm{mg} / \mathrm{l}$ of cyanide until it further dropped to $82 \%$, at which there was a gradual decline in COD removal efficiency.

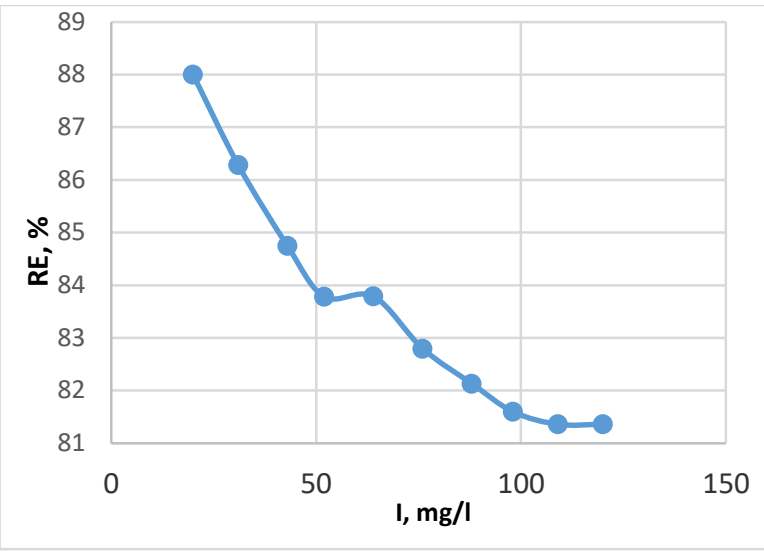

Figure 4: Effect of cyanide inhibitor on COD removal efficiency.

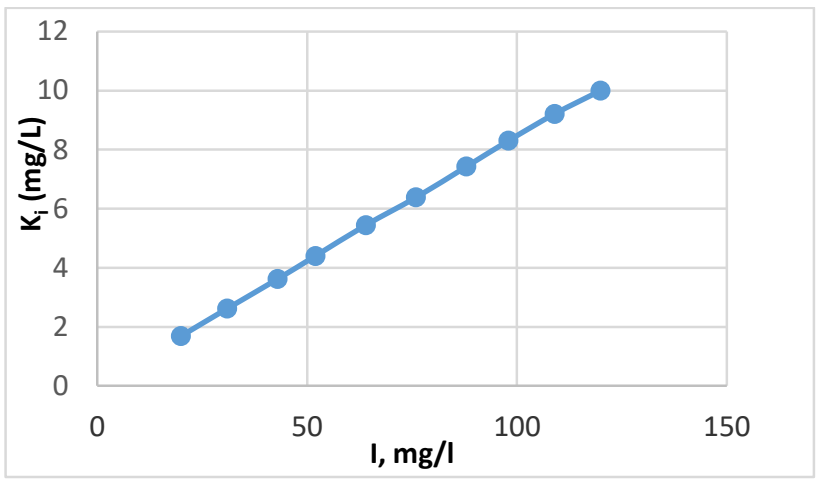

Figure 5: Degree of dependence of inhibitor constant, Ki on cyanide concentration, I.

\section{Optimal Model for COD Removal in Cassava Wastewater}

This was observed at cyanide concentration of $110 \mathrm{mg} / \mathrm{l}$. When Potivichayanon et al. (2020) compared the fixed-film sequencing batch reactor (F-SBR) with that of a conventional sequencing batch reactor (SBR), the cyanide and COD removal efficiencies of the SBR were $42.61 \%$ and $36.83 \%$, respectively, while those of the F-SBR were $77.95 \%$ and $74.43 \%$ and the F-SBR was very effective for the complete removal of cyanide when the hydraulic retention time was increased to 10 days. This efficiency was similar to the efficiency of COD removal in this study, which reached 88$84 \%$ efficiency with the ABR system. These results showed that the immobilization of cyanide-degrading bacteria such as Agrobacterium tumefaciens SUTS 1 and Pseudomonas monteilii SUTS 2 carried out with a polypropylene ring in a fixed-film aerobic system enhanced the improved performance of the F-SBR.

Table 5 shows the four-factor, ten level experiment runs with observed values for COD removal efficiency. The data in Table 5 was used to calibrate the model that would govern the effect of the four parameters $\mathrm{L} / \mathrm{W}, \mathrm{N}_{\mathrm{b}}, \mathrm{K}_{\mathrm{i}}$ and $\mathrm{Q}$ on the COD removal efficiency, RE, as:

$$
R E=0.8304(L / W)^{0.0193}\left(N_{b}\right)^{0.0011}\left(K_{i}\right)^{0.012}(Q)^{0.016}
$$

For the COD removal efficiency in cassava wastewater, positive values of 0.0193 and 0.0011 were respectively 
estimated as the exponents of the aspect ratio (L/W) and number of baffles $\left(\mathrm{N}_{\mathrm{b}}\right)$, implying that the COD removal efficiency increases exponentially as the number of baffles and aspect ratio of the reactor increases.

Table 5: $4^{10}$ Factorial model with observed cod removal efficiency.

\begin{tabular}{cccccc}
\hline Case & $\mathbf{L} / \mathbf{W}$ & $\mathbf{N}_{\mathbf{b}}$ & $\mathbf{K}_{\mathbf{i}}$ & $\mathbf{Q}$ & $\mathbf{R E}$ \\
\hline 1 & 0.4 & 3 & 9.9989 & 0.4 & 0.813614 \\
2 & 0.5 & 4 & 9.2079 & 0.3148 & 0.813592 \\
3 & 0.6 & 5 & 8.3002 & 0.2796 & 0.816 \\
4 & 0.7 & 6 & 7.4252 & 0.2444 & 0.82132 \\
5 & 0.8 & 7 & 6.3827 & 0.2092 & 0.827979 \\
6 & 0.9 & 8 & 5.4414 & 0.1739 & 0.837895 \\
7 & 1 & 9 & 4.3996 & 0.1287 & 0.837838 \\
8 & 1.1 & 10 & 3.6196 & 0.1035 & 0.847514 \\
9 & 1.2 & 11 & 2.6198 & 0.0683 & 0.862857 \\
10 & 1.3 & 12 & 1.6901 & 0.0331 & 0.88 \\
\hline
\end{tabular}

Thus, there is clearly a positive correlation between the COD removal efficiency in cassava wastewater, the aspect ratio $(\mathrm{L} / \mathrm{W})$ and number of baffles $\left(\mathrm{N}_{\mathrm{b}}\right)$, although the aspect ratio shows higher correlation than the number of baffles. This agrees with the findings of Watthier et al. (2019) who used horizontal anaerobic fixed bed reactor to remove organic matter from cassava wastewater and the results showed that the COD removal efficiency increased with the organic loading rate, thus resulting in COD removal values of up to $99 \%$. Conversely, cyanide inhibition constant $\left(\mathrm{k}_{\mathrm{i}}\right)$ and the flow rate of the reactor inversely correlated with the COD removal efficiency (CE). These factors, thus have negative effects on the COD removal efficiency such that any decrease in any of the factors caused a decrease in the amount of COD removed.

The goodness of fit of the developed model was validated by estimating the coefficient of determination $\left(\mathrm{R}^{2}\right)$ as 0.997 implying an adequate model. With the objective function for COD removal defined as Equation 8 and the range of independent functions given in Table 5 as the model constants, the response surface methodology was used to obtain the optimum condition for maximum COD removal using the numerical optimization tool built in the Design-Expert 9.0.4.1 statistical software. This was used to combine the desirable ranges for the response to obtain a simultaneous objective function as given by Myers et al. (2004) in Equation (8).

$D=\left(d_{1} \times d_{2} \times \ldots \times d_{n}\right)^{1 / n}=\left(\prod_{i-1}^{n} d_{i}\right)^{1 / n}$

where $D, d_{i}$, and $n$ are the desirability objective function, response range, and the number of responses, respectively.

In this case, the response which is the percent removal of COD $\left(d_{1}\right)$ was maximized. Hence, the following optimum conditions to reach a maximum COD removal efficiency of 99\% were found: reactor aspect ratio (10), number of baffles (20), cyanide inhibition constant $(30 \mathrm{mg} / \mathrm{l})$ and influent flow rate $(0.8 \mathrm{1} / \mathrm{min})$. Several authors have studied the effect of aspect ratio $(\mathrm{L} / \mathrm{w})$ on $\mathrm{COD}$ removal in $\mathrm{ABR}$ system and reported that the optimum aspect ratio for COD removal is the range of 0.5 to 1.5 (Marquardt, 1995; Parker and Doyle III, 2001; Fredrickson et al., 1970). Zamamiri (2002) studied the influence of number of baffles on COD removal efficiency in bioreactors and obtained the range of value 2 and 15. This is in agreement with the results obtained in this study.

\section{CONCLUSION}

The objective of this study was the evaluation of the performance of the ABR during various hydraulic and loading conditions of cassava wastewater. A new model for optimal COD removal from cassava wastewater treatment was developed using for the ABR system using the RSM. Evaluation of optimum number of baffles and aspect ratio for the treatment of cassava wastewater was achieved,

The mathematical model for cassava wastewater treatment was successfully calibrated and validated in an ABR system. When fitted to experimental data, the Monod models showed a better description of cassava wastewater treatment in the ABR system than the Michealis-Menten model. The effect of $\mathrm{N}_{\mathrm{b}}$ and $\mathrm{L} / \mathrm{W}$ on the COD removal efficiency showed that their values increased as COD removal efficiency. Although, the impact of flow rate $\mathrm{Q}$ and $\mathrm{K}_{\mathrm{i}}$ on the cyanide concentration revealed optimum values, further studies are required for the optimization of methane production from cassava wastewater treated in the ABR.

\section{REFERENCES}

Adegoke, A.T.; B.E. Olowu; N.S. Lawal; O.A. Odusanya; O.B. Banjo; O.B. Oduntan and B.D. Odugbose (2020). The impact of cassava wastewater from wet fufu paste processing industry on surrounding soil: a case study of Ayetoro community, Ogun State, Nigeria. J. Degrade. Min. Land Manage. 7(7): 2319-2326, doi: 10.15243/jdmlm. 2020.074.2319.

Adewoye S.O.; O.O. Fawole; O.D. Owolabi and J.S. Omotosho (2005). Toxicity of Cassava Wastewater Effluents to African Catfish: Clarias Gariepinus. Ethiopian Journal of Science, 28(2):189-194.

Agunwamba, J.C.; N.C. Oti and I. Aguwa (2001). Treatability of Cassava wastewater and sewage: batch reactor studies. J. Sci. Engr. Tech, 8(1): 3096-3107.

Agunwamba, J.C. (2004). Degradation of glucoside in Cassava Wastewater. African J. of Science, 5(1):1174-1185.

Eze, S.O. and Azubuike, A. (2010). Assessment of the physicochemical properties and applications of some Cassava varieties. Research Journal of Applied Sciences, 5(4):309.

FEPA (1991). Federal Environmental Protection Agency. S.1.8. National environmental protection (Effluent Limitations).

Fredrickson, A.G.; R.D. Megee III and H.M. Tsuchiya (1970). Mathematical models for fermentation processes. Adv. Appl. Microbial., 13:419.

Ibeje, A.O; H. I. Mbachu, and V. A. Wirnkor (2019). Experimental Design for Optimal Removal of PAH from Crude Oil Waste using Aerobic Bioreactor. International Journal of Darshan Institute on Engineering Research and Emerging Technologies 8(1): 18-21.

Ibeje, A. O. and Okoro, B.C. (2013). Mathematical Modeling of Cassava Wastewater Treatment Using Anaerobic Baffled Reactor. American Journal of Engineering and Science. 2 (5): 128 - 134.

Igwe, C.E. and Azorji, J.N. (2018). Influence of Cassava Mill Effluent on the Growth Rate of Two Selected Arable Crop Species (Zea mays and Vigna unguiculata L). Journal of 
Bioremediation \& Biodegradation 9:444, 9(4). doi: 10.4172/2155-6199.1000444

Mantzaris N.V.; F. Srienc and P. Daoutidis (2002). Nonlinear productivity control using a multi staged cell population balance model. Chem. Eng. Sci. 57:1-14

Marquardt, W. (1995). Towards a process modeling methodology. In: Methods of model-based process control. Kluwer Academic Publishers: 3-40.

Myers, R.H.; D.C. Montgomery; G.G. Vining; C.M. Borror and S.M. Kowalski (2004). Response Surface Methodology: A Retrospective and Literature Survey. Journal of Quality Technology, 36:53-77.

Nguyen T. L.; T.R. Preston and B. Olge (1997). Cassava root silage for croobred pigs under village conditions in central Vietnam. Livest. Res. Rural Dev. (9) 2: 12-19.

Nigerian Industrial Standard (NIS) 554 (2007). NIS. Nigerian Standard for Drinking Water Quality. Document No. ICS 13.060.20: 16-17.

Ogboghodo, I.A.; I.O. Oemwota; S.O. Eke and A.E. Iribhogbe (2001). Effect of Cassava (Manihot esculenta crantz) mill grating effluent on the textural, chemical and biological properties of surrounding soils. World J. Biotechnol. 2: 292-301.

Oghenejoboh, K. M. (2015). Effects of Cassava Wastewater on the Quality of Receiving Water Body Intended for Fish Farming. British Journal of Applied Science \& Technology 6(2): 164-171. doi: 10.9734/BJAST/2015/14356

Okunade, D.A. and Adakalu, K.O. (2013). PhysicoChemical Analysis of Contaminated Water Resources Due to Cassava Wastewater Effluent Disposal. European Journal of Science and Technology 2 (6): 75-78.

Olayinka, A.S. (2013). Assessment of toxic potentials of Cassava effluent on Clarias Gariepinus. International Journal of Agricultural Science and Research. 3(3):157.

Onukwugha, E. R. (2015). Mathematical Modelling for Cassava Wastewater Treatment System. Unpublished Ph.D. Thesis, Department of Civil Engineering, Federal University of Technology, Owerri.
Onukwugba, E. and Ibeje, A. O. (2013). Mathematical Modeling of Cyanide Inhibition on Cassava Wastewater Treatment. American Journal of Engineering and Science. 2(9): 190 - 197.

Onukwugha, E.; B. C. Okoro; J. C. Agunwamba and A. O. Ibeje (2016). Scale Effects of Physical Modelling of Anaerobic Treatment Plants in the Treatment of Cassava Wastewater. International Journal of Sciences 5(11): 23-35. doi: 10.18483/ijsci.1127

Parker, R.S. and Doyle III, F.J., (2001). Optimal control of a continuous bioreactor using an empirical non-linear model. Ind. Eng. Chem. Res. 40:1939-1951.

Potivichayanon, S.; R. Toensakes; N. Supromin and K. Seaung (2020). Removal of High Levels of Cyanide and COD from Cassava Industrial Wastewater by a Fixed-Film Sequencing Batch Reactor. Water, Air, \& Soil Pollution 231(301)

Ribas, M.M.F.; M.P. Cereda and R.L.V. Bôas (2010). Use of Cassava Wastewater Treated Anaerobically with Alkaline Agents as Fertilizer for Maize (Zea mays L.). Brazilian Archives of Biology and Technology. 53:55-62.

Ubalua O. (2007). Cassava wastes: treatment options and value addition alternatives. African Journal of Biotechnology, 6 (18): 2065-2073.

Ugwu, E. I. and Agunwamba, J. C. (2012). Detoxification of Cassava wastewater by alkali degradation. Journal of Research in Environmental Science and Toxicology, 1(7): 161-167.

Watthier, E.; C.I. Andreani; D.G.B. Torres; O. Kuczman; M. H. F. Tavares; D. D. Lopes and S. D. Gomes (2019) Cassava Wastewater Treatment in Fixed-Bed Reactors: Organic Matter Removal and Biogas Production. Front. Sustain. Food Syst., doi: 10.3389/fsufs.2019.00006

WHO. (2006). Guidelines for drinking water quality, Frit Addendum to Third edition. 1: 211-213.

Zamamiri A.M.; Y. Zhang and M.A. Hjortso (2002). Dynamics analysis of an age distribution model of oscillating yeast cultures. Chem. Eng. Sci. 57:2169-218. 